\title{
Henry Fayol and Frederick Winslow Taylor's Contribution to Management Thought: An Overview
}

\section{Md. Hasebur Rahman}

Lecturer, Department of Business Administration, Pabna University of Science and Technology, BANGLADESH

\begin{abstract}
Henry Fayol and Frederick Winslow Taylor made outstanding contribution to development of management thought. Fayol wrote as a practical man of business reflecting on his long managerial career and setting drown the principles he had observed. He clearly specified the functions of management by a systematic analysis of management process. This isolation and analysis of management as a separate discipline was his original contribution to the body of management theory. He was father of management principles many of which have stood the test of time. Frederick W. Taylor was a pioneer who propounded principles of Scientific Management. Taylor worked in different capacities in steel industry saw the urgent necessity for elimination of wastages rampant in industrial organization. He observed that the only way to attract wastages and achieve efficiency to apply method of science to the field of management. They both applied scientific methods to the problems of management. Their work was essentially complementary; different in their approach was merely reflection of their different careers. If we call Taylor the "Father of Scientific Management", it would be fair to describe Fayol as the "Father of Management".
\end{abstract}

Key words: Management thought, scientific management, management principles, Henry Fayol, Frederick Winslow Taylor

\section{INTRODUCTION}

Fayol's pride of place in management due to his principles of how to manage, as to his famous definition of management. Fayol's theoretical analysis of management withstood almost a half-century of critical discussion. There have been few writers since who have not been influenced by it; and his five elements have provided a system of concepts by which managers may clarify their thinking about what is they have to do. Fayol's valuable concepts in management can be incorporated usefully in present-day analysis of management science. His emphases on unity of direction and command, non-financial incentives, decentralization, coordination have greater relevance even today.

Frederick Winslow Taylor contributed a number of principles and features of management thought that adhered to his new concept of approaching management thought scientifically. Scientific Management tries to increase productivity by increasing efficiency and wages of 
the workers. It finds out the best method for performing each job. It selects employees by using Scientific Selection Procedures. It provides Scientific Training and Development to the employees. It believes in having a close co-operation between management and employees. It uses Division of Labor. It tries to produce maximum output by fixing Performance Standards for each job and by having a Differential Piece-Rate System for payment of wages. Scientific management is concerned with knowing exactly what you want men to do and then see in that they do it in the best and cheapest way (Taylor, 1911)

Works Henry Fayol and Frederick Winslow Taylor are essentially complementary; they made outstanding contribution to development of management thought. They believed that proper management resource is the key reason for organizational success. Both use scientific approach to management. There major difference was in their orientation. Fayol emphasized the management of entire organization while Taylor focused on the management of operational work.

\section{LITERATURE REVIEW}

In management literature today, the greatest use of the term "Principles of Management" and "scientific management" with the reference of Fayol and Taylor regarded as Father of Management and Scientific Management respectively. Fayol's theories were the original foundation for management as a discipline and as a profession. Also Fayol was the first to advocate management education (Pryor and Sonia, 2010). Scientific management was one of the first attempts to systematically treat management and process improvement as a scientific problem (Wikipedia, 2013).

Fayol is best remembered for his contribution to school of management thought. First, Fayol believed that organizational and business life was an amalgam of six activities - technical; commercial; financial; security; accounting; and management (Fayol, 1949; Parker and Ritson, 2005b; Bakewell, 1993). Second, Fayol is known for the five elements or functions of management, i.e. planning, organizing; coordination; command; and control (Fayol, 1949; Wren, 1972; Breeze, 1985; Robbins et al., 2000). Gulick expanded Fayol's functions of management from five to seven by adding staffing, directing, reporting, and budgeting to planning, organizing, and coordinating. Finally, Fayol advocated 14 principles of management designed to guide the successful manager (Fayol, 1949; Armstrong, 1990; Breeze, 1985; Wren, 1972). Fayol's 14 principles of management are: division of work; authority; discipline; unity of command; unity of direction; subordination of individual interests to the general interests; remuneration; centralization; scalar chain; order; equity; stability of tenure of personnel; initiative; and esprit de corps (Fayol, 1949, pp. 19-42; Cole, 1984, pp. 13-14). Fayol's theories continue to be valuable contributions to management because many management experts consider his 14 principles of management to be the early foundation of management theory as it exists today (Wren, 1994, 1995; Bartol et al., 2001; Bedian and Wren, 2001; Rodrigues, 2001; Wren, 2001; Breeze and Miner, 2002; Robbins et al., 2003).

Frederick W. Taylor, the father of Scientific Management, was an American mechanical engineer, efficiency expert, and management consultant. In 1911 he published his seminal work, The Principles of Scientific Management, in which he laid out the process of scientifically studying work to increase worker and organizational efficiency. The principles underlying his theory contributed to a wide array of management practices during the 20th century including task specialization, assembly line production practices, job analysis, work design, incentive schemes, person-job fit, and production quotas and control (Giannantonio, C. M. and Hurley-Hanson, 2011). The impact of Taylor's work on the field of management 
has long been recognized by management scholars. Wren and Hay's (1977) study saw Taylor at the top of the list among contributors to American management thought and practice. Heames \& Breland's (2010) study found Taylor to be at the top of their list thirty years later. The Principles of Scientific Management, not only tops Bedeian and Wren's (2001, p. 222) list of the 25 most influential management books of the 20th century, but they refer to it as "The most influential book on management ever published." The 100th anniversary of the publication of his book offers a unique opportunity to reflect on the relevance of Taylor's ideas in the 21st century. One hundred years later Principles of Scientific Management remains a lasting contribution to the development of management thought. Taylor continues to dominate any list of persons who have made business management a worthy calling and a fitting topic to study. His reach was international and to a broad spectrum of audiences and his ideas shaped how we live and think today (Wren D. A., 2011).

\section{ObJectives OF THE Study}

Considering the significance of Henry Fayol's and Frederick Winslow Taylor's contribution to management thought, the study is taken for three fold of objectives:

- To outline Henry Fayol's contribution to management thought;

- To outline Frederick Winslow Taylor's contribution to management thought; and

- To compare and contrast Henry Fayol and Frederick Winslow Taylor's contribution to management thought.

\section{Methodology}

This study is based on theoretical perspective of historical contribution of two scholars of management theory namely, Henry Fayol and Frederick Winslow Taylor. This descriptive study is initiated for overviewing contribution of these scholars by viewing original work done by them. For better acknowledgement of their work scholastic articles and related book has been overviewed for serving purpose of that study that are available at library resources.. Relevant analysis and comments on Henry Fayol and Frederick Winslow Taylor works have been consolidated from internet data resources by different authors.

\section{HenRy Fayol (1841-1925); Father of Modern Management}

The earliest manager to systematically examine his own personal experience and try to draw from it a theory of management was Henri Fayol. A qualified mining engineer, he was made manager of a coal- mine at the early age of 25 . At 31 he became general manager of a group of mines, and at 47 managing director of whole combine, a post which he held for thirty years. Throughout his career he showed all the sings of a successful manager. This become most obvious, when he took over the top job of the combine, which was almost bankrupt. By the time he retired the business was more than twice its original size and one of the successful and steel combines in Europe. In 1916 he published the book "Administration Industrielle et Ge'ne'rale" which deplorably was not available in English transaction until 1929. It is better known, at any rate in the United Kingdom, as General and Industrial Management, in the translation by Constance Storrs, published by Pitman in 1949. Fayol's major contribution was to identify management as a separate set of skills, or functions, performed by supervisors in organizations. He clearly delineated the difference between technical and managerial skills and noted that supervisor must be proficient in both to be successful. Fayol in his preface in his boob say's management plays very important part in government; of all undertakings, large or small, industrial, 
commercial, political, religious or other. Fayol wrote as a practical man of business reflecting on his long managerial career and setting drown the principles he had observed. He was not attempted to develop a logical theory or a self-contained philosophy of management. His observations, however, fit amazingly well into the currently developing mold of management theory.

\section{Contribution of Henry Fayol on Management Thought}

Industrial Activities: Fayol (1949) suggest that "All activities to which industrial undertakings can be divided in to the sig groups: A. Technical activities (Production, Manufacture); B. Commercial activities (Buying, Selling and Exchange); C. Financial activities (Search for and optimum use of capital); D. Security activities (Protection of property and person); E. Accounting activities (Stocktaking, Balance Sheet, Cost, Statistics); F. Management activities (Planning, Organizing, Command, Coordination, Control).

Elements of Management: Fayol's (1949) answer was unique at the time. The core of his contribution is his definition of management ("To forecast and plan, to organize, to command, to coordinate and to control") as comprising five elements (Gulick and Urwick, 1937): To forecast and plan: Examining the future and drawing up the plan of operation; To organize: Building up the structure, material and human of the undertaking; To command: Maintaining activity among the personnel; To coordinate: Building together, unifying and harmonizing all activities and effort; To control: Seeing that everything occurs in conformity with established rules and expressed command.

General Principles of Management: Fayol (1949) summarizes a number of General Principles of Management on his own personal experience and observation, most become part of managerial know-how many are regarded as fundamentals tenets. Fayol outlines the fourteen principles: Division of labor: Concept of specialization at work; Authority: The right to give order and the power to exact obedience; Discipline: Based on obedience and respect. Unity of command: Each employee should receive orders from only one superior; Unity of direction: One boss and one plan for a group of activities having the same objective; Subordination of individual interest to the general interest: To abolish the tendency of placing individual interest ahead of the group interest; Remuneration: Employees should receive fair payment of service. Centralization: Consolidation of management functions. Decisions are made from the top. Scalar chain: Formal chain of commanding run from the top to bottom of the organization; Order: All materials and personnel have a prescribed place, and they must be remained there; Equity: Resulted from kindness and justice; Stability of tenure: Limited turnover of personnel. Life time employment for good workers; Initiative: Call for individual zeal and energy in all efforts; and Sprits de crops: Stressed the building of harmony and unity within the organization. Fayol was a firm believer that if organizational leaders used his theories, including the 14 principles of management, they would be able to achieve performance excellence. For example, the principle of division of labor would help employees be more efficient by specializing in different tasks (Fayol, 1949; Meier and Bohte, 2000). Rodrigues (2001) agreed that an organization's proper implementation of Fayol's 14 principles of management would lead to organizational efficiency and effectiveness. He especially supported the concept of continuous training of personnel. Training is important because it not only improves employees' skills, knowledge, and competencies, but it also enhances organizational capacity, capability and performance which are essential ingredients for organization effectiveness and are the foundation of an organization (Rodrigues, 2001). 
Qualities of Manager: According to Fayol (1949) the business requires a basis in the people who carry them out: a) Physical qualities; b) Mental qualities; c) Moral qualities; d) General education; e) Special knowledge of the function concerned; and f) Experience. Fayol draws the conclusion that the major ability required in the managerial function. However good technical or other ability may be, if the managerial function is week the business will not be succeed. He made a point that management is not being taught along with the technical subject because there is no theory of it to teach. An adequate theory is essential.

Managerial Duties of an Organization: To organize a business is to provide it with everything useful for its functioning: raw materials, tools, capital, personnel. All these may be divided into two main sections, the material organization and the human organization. According to Fayol, manager concerned only with the human organization. Seemingly out of place, sixteen managerial duties of an organization follow the definition- Ensure that the plan is judiciously prepared and strictly carried out; See that the human and material organization is consistent with the objective, resources, and requirements of the concern; Set up a single, competent energetic guiding authority; Harmonize activities and coordinate efforts; Formulate clear, distinct, precise decisions; Arrange for efficient selection-each department must be headed by a competent, energetic man, each employee must be in that place where he can render greatest service; Define duties clearly; Encouraging a linking for initiative and responsibility; Have fair and suitable recompense for service rendered; Make use of sanctions against faults and errors; See the maintenance of discipline; Ensure that individual interests are subordinated to the general interest; Pay special attention to the unity of command; Supervise both material and human order; Have everything under control; and Fight against excess of regulations, red tape and proper control.

Command: According to Fayol (1949), the purpose of command is to set the human organization in motion towards its objectives. Its objective is to get optimum return from all employees. To command effectively- The manager must know its employees; get rid of the incompetent; know the employer-employee agreements; Set a good example; periodically review organization; Use conferences with the subordinates to ensure unity of direction, delegate the details and establish esprit de corps. Fayol wrote as the practical man of business reflecting on his long managerial career and setting down the principles he had observed. His observation fit amazingly well into the currently developing would of management theory. Since all enterprise require managing, the formulation of a theory of management is necessary to its effective teaching (Weihrich H. and Koontz H., 1994).

\section{FREDERICK WinsLOW TAYLOR (1856-1915); FATHER OF SCIENTIFIC MANAGEMENT}

Taylor was an engineer by training. He joined the Midvale Steel Works as a laborer and rose rapidly to be foreman and rose to the position of chief engineer after earning a degree in engineering through evening study. He was afterwards employed at the Bethlehem Steel Works, than become a consultant and devoted his life to the propagation of his ideas. Frederick W. Taylor (1856-1915) was a pioneer who propounded principles of "Scientific Management (1911)" come to be recognized as the father of scientific management. Scientific management also called Taylorism (Aitken, Hugh G.J., 1985). Taylor is renowned for his research and work into management thought and scientific management. His 
suggested principles and features have helped model the scientific approach to management. Its main objective was improving economic efficiency, especially labor productivity (Wikipedia, 2013). He was primarily concerned with efficiency of workers and optimum utilization of machines and other resources in order to bring up a sound enterprise consistent with the interest of entrepreneurs, the laborers and the customer at large. Taylor worked in different capacities in steel industry saw the urgent necessity for elimination of wastages rampant in industrial organization. The only way to attract wastages and achieve efficiency to apply method of science to the field of management. The first published his views on management in a paper entitled "A price rate system", 1895. The views were expanded into a book "Shop Management", 1903 and further developed in "Principles of Scientific Management", 1911.

Taylor was the founder of the movement known as "Scientific Management". The principal object of management, he states "should be to secure the maximum prosperity of each employer coupled with the maximum prosperity of each employee". For the employer, "maximum prosperity" means not just large profits in the short run but the development of all aspects of the enterprise to a state of permanent prosperity. For the employee, "maximum prosperity" means not just immediate higher wages, but his development, so that he may perform efficiently in the high grades of work for which his natural abilities fit him.

Change in the mental attitude of employers and an employee toward each other

in respect of work was the root of Scientific Management.

His ideas speared in the United States, France, Germany, Russia, and Japan, and inspired others to study and developed the methods of scientific management

\section{Contribution of Frederick Winslow Taylor on Management Thought}

Contribution of Frederic Winslow Taylor can be discussed into three phases: 1). Principles of Management; 2). Mechanism of Management; and 3). Philosophy of Management.

Principles of Management: The fundamental principles that Taylor (1911) saw underlying the scientific approach to management are-

A. The development of a scientific method of designing jobs to replace the old rule-of-thumb methods; this involved gathering, classifying and tabulating data to arrive at the "one best way" to perform a task or series of task.

B. The scientific selection and progressive teaching and development of employees; Taylor show the value of matching the job to the worker. He also emphasized the need the study worker strengths and weakness and to provide training to improve workers performance.

C. Bringing together of scientifically selected employees and scientifically developed methods for designing jobs; Taylor believed that new and scientific methods of job design should not merely be put before an employee; they also should be fully explained by management. He believed that employees would show little resistance to changes in methods if they understood the reasons for the change and they show a change for greater earnings for themselves.

D. Division of work resulting in an interdependence between management and the worker; Taylor felt that if they were truly dependent on one another, than cooperation would naturally follow.

Mechanism of Management: He put the right person on the job with the correct tools and equipment, had the worker follow his instruction exactly, and motivated the worker with an economic incentive of a significant higher daily wages. Based on his 
groundbreaking studies of manual work using scientific principles, Taylor became known as the "Father" of scientific management (Robins S. P., Coulter M. and Vohra N., 2010). Standardization, time and motion studies, functional foremanship, production planning and control, price wage system of payment on differential basis were the main ideas enunciated by Taylor.

Philosophy of Management: Scientific management was a complete mental revolution for both management and employees towards their respective duties towards each other (Taylor, 1911). It was a new philosophy and attitude towards the use of human efforts. Thus Taylor advocated a philosophy of management under which management would undertake a basic responsibility of planning and control and prescribe the rules, laws and formulas to guide the actual operations by man and machines, so as to help employees to produce at lower cost to the employer and with more remuneration to themselves. Management should evolve laws of standard work and rules for workmeasurement. Workers should be trained in advance in detail. Detailed instruction in writing should be issued to workers regarding the task to be done and methods to be used in completing the task. What, how and when the work is to be performed is to be included in management plan. Taylor shorted the management to motivate the personnel not merely by giving orders, show the authority etc. but by selecting, teaching and developing the workmen and heartily co-operating with them.

\section{FAYOL Vs TAYLOR}

Attempts have been made to compare and contrast the work of Fayol and Taylor. The works of Fayol and Taylor are essentially complementary. Both believed that proper management of personnel and other resources was the key organizational success. Both use scientific approach to management. Berdayes (2002) suggests that the following are ideas of Fayol and Taylor that unite their work:

- Work processes, organizational structures, and an emphasis on a hierarchical division of labor.

- Creation of the concept of the organization as a whole (Fayol delineated clear lines of authority into a conceptual and functional unity, and similarly Taylor emphasized formalization of work processes into a total organization).

- Emphasis on formal rationality by supporting scientific techniques, order, and efficiency.

- The role of managers is to work with and encourage their workers. Taylor (1947) indicated that managers should work along with the workers, helping, encouraging, and smoothing the way for them. However, he also sought to change their mental attitudes and behaviors on the basis of scientific principles so as to improve operational efficiency. Along this same line, Fayol (1949) noted that need to determine their workers abilities, encourage and train them, and reward enthusiasm, initiative and success.

There major difference was in their orientation. Fayol stressed the management of organization while Taylor stressed the management of operative work. Fayol wrote during the same time period as Taylor. Fayol attention was directed as the activities of all managers while Taylor was concerned with first line managers and the scientific method, Fayol wrote from personal experience as he was the managing director of a large French coal-mining firm. 
Table \# 01

\begin{tabular}{|l|l|l|}
\hline \multicolumn{1}{|c|}{ Basis of Comparison } & \multicolumn{1}{|c|}{ Henry Fayol } & \multicolumn{1}{|c|}{ Frederick Winslow Taylor } \\
\hline 1. Perspective & Top management & Shop floor level \\
\hline 2. Focus & $\begin{array}{l}\text { Improving overall } \\
\text { administration through } \\
\text { general principles }\end{array}$ & $\begin{array}{l}\text { Improving productivity } \\
\text { through work simplification } \\
\text { and standardization }\end{array}$ \\
\hline 3. Personality & Practitioner & Scientist \\
\hline 4. Results & $\begin{array}{l}\text { Universal truths developed } \\
\text { from personal experiences }\end{array}$ & $\begin{array}{l}\text { Scientific observation and } \\
\text { measurement }\end{array}$ \\
\hline 5. Major Contribution & $\begin{array}{l}\text { A systematic theory of } \\
\text { management }\end{array}$ & $\begin{array}{l}\text { Science of industrial } \\
\text { management }\end{array}$ \\
\hline \multicolumn{2}{|l|}{ Comparison between Henry Fayol and Frederick Winslow Taylor }
\end{tabular}

Fayol observed management from the top down while Taylor worked at management from the bottom up. Fayol was a top manager and was obviously in a better position than Taylor to observe the functions of a manager. Fayol's main concern was to improve the management of total organization while Taylor concentrated on improving the management of jobs. Therefor Fayol's administrative theory has a wider application than Taylor's Scientific Management.

\section{Conclusions}

Henry Fayol made outstanding contribution to management thought. He made a clear distinction between operational activities and managerial activities. He clearly specified the functions of management by a systematic analysis of management process. This isolation and analysis of management as a separate discipline was his original contribution to the body of management theory. Fayol firmly advocated that management should be formally taught. He also highlighted the universal characteristics of management principles. He was father of management principles many of which have stood the test of time. He developed a framework for further study and research. One of the greatest contributions of Fayol is that his ideas pave the way for developing the theory of management. However Fayol's works has been criticized on several counts- Firstly, his theory is said to be too formal. Secondly, he did not pay adequate attention to worker. Thirdly, there is vagueness and superficiality about some of his terms and conditions. Fourthly, he hinted at but did not elaborate that management can and should be taught. Despite of these limitations, Fayol made a unique and outstanding contribution to management theory.

Taylor's ideas, research and recommendations brought into focus technological, human, and organizational issues in industrial management. Benefits of Taylorism included wider scope for specialization, accurate planning, timely delivery, standardized methods, better quality, lesser costs, minimum wastages of materials, time and energy and cordial relationship between the management and workmen. Worker earned more wages, employees saved their cost, turned out larger and better output and customer got in lighted with planning and doing. Taylor improved management methods by emphasizing the concept of work measurement. He developed the techniques of measure quantities, designed wage incentive scheme and lacked the problems of organizing complex 
manufacturing activities. Taylor concept of scientific management provoked critical comments; his theory is concerned with factory management, one side benefit of employees does not consider human factor at work. His theory builds on economic man concept, human is regarded as machine.

There is, however, no contradiction between the work of Taylor and Fayol. They both applied scientific methods to the problems of management. Their work was essentially complementary; different in their approach was merely reflection of their different careers. If we call Taylor the "Father of Scientific Management", it would be fair to describe Fayol as the "Father of Management".

\section{Reference}

Aitken, Hugh G.J. (1985), Scientific Management in Action: Taylorism at Watertown Arsenal, 1908-1915, Princeton, NJ, USA: Princeton University Press,

Armstrong, M. (1990), Management Process and Function, Short Run Press, Exeter.

Bakewell, K.G.B. (1993), "Information: the seventh management function", Information and Security Management Journal, Vol. 1 No. 2, pp. 29-33.

Bartol, K., Martin, D., Tein, M. and Matthews, G. (2001), Management: A Pacific Rim Focus, 3rd ed., McGraw-Hill, Roseville, CA.

Bedeian, A.G. \& Wren, D.A.(2001). Most Influential Management Books of the $20^{\text {th }}$ Century. Organizational Dynamics, 29(3): 221-225.

Bedian, A.G. and Wren, D.A. (2001), "Most influential books of the 20th century", Organizational Dynamics, Vol. 29 No. 3, pp. 221-5.

Berdayes, V. (2002), "Traditional management theory as panoptic discourse: language and the constitution of somatic flows", Culture and Organization, Vol. 8 No. 1, pp. 35-49.

Breeze, J.D. (1985), "Harvest from the archives: the search for Fayol and Carlioz", Journal of Management, Vol. 11 No. 1, pp. 43-54.

Breeze, J.D. and Miner, C.F. (2002), "Henri Fayol: a new definition of 'Administration'", in Wood, J.C and Wood, M.C. (Eds), Henri Fayol: Critical Evaluation in Business and Management, Routledge, London, pp. 110-13.

Cole, G.A. (1984), Management: Theory and Practice, Guernsey Press, Saints Bay.

F.W.Taylor, Scientific Management (1911), Harper Brothers, New York

Fayol, H. (1949), General and Industrial Management, Sir Isaac Pitman \& Sons, London (translated by Constance Storrs).

Giannantonio, C. M. and Hurley-Hanson, A. E. (2011), Frederick Winslow Taylor: Reflections on the Relevance of the Principles of Scientific Management 100 Years Later, Journal of Business and Management - Vol. 17, No. 1,pp. 07.

Gulick and Urwick (1937), Papers, Chapter 5.

Heames, J.T. \& Breland, J.W. (2010). Management Pioneer Contributors: 30-Year Review. Journal of Management History, 16(4): 427-436.

http://en.wikipedia.org/wiki/Scientific_management\#cite_ref-Taylor1911_10-0. Retrieved July 20, 2013.

http://en.wikipedia.org/wiki/Scientific_management. Retrieved July 24, 2013.

Meier, J.K. and Bohte, J. (2000), "Ode to Luther Gulick span of control and organizational performance", Administration and Society, Vol. 32 No. 2, pp. 115-37.

Mildred Golden Pryor and Sonia Taneja (2010), Henri Fayol, practitioner and theoretician - revered and reviled, Journal of Management History Vol. 16 No. 4, pp. 489-503, Emerald Group Publishing Limited

Parker, L.D. and Ritson, P. (2005), "Revisiting Fayol: anticipating contemporary management", British Journal of Management, Vol. 16, pp. 175-94.

Robbins, S.P., Bergman, R., Stagg, I. and Coulter, M. (2000), Management, 2nd ed., Prentice-Hall, Sydney. 
Robbins, S.P., Bergman, R., Stagg, I. and Coulter, M. (2003), Foundations of Management, Prentice-Hall, French's Forest.

Robins S. P., Coulter M. and Vohra N. (2010), Management, Prentice Hall (Pearson), Indian Tenth Edition.

Rodrigues, C.A. (2001), "Fayol's 14 principles of management then and now: a framework for managing today's organizations effectively", Management Decision, Vol. 39 No. 10, pp. 880-9.

Taylor, Frederick Winslow (1911), The Principles of Scientific Management, New York, NY, USA and London, UK: Harper \& Brothers

Weihrich H. and Koontz H. (1994), Management A Global Perspective, McGraw-Hill, Inc. Tenth Edition.

Wren D. A.(2011), The Centennial of Frederick W. Taylor's The Principles of Scientific Management: A Retrospective Commentary, Journal of Business and Management - Vol. 17, No. 1, pp. 19.

Wren, D.A. \& Hay, R.D. (1977). Management Historians and Business Historians: Differing perceptions of pioneer contributions. The Academy of Management Journal, 20(3): 470-476.

Wren, D.A. (1972), The Evaluation of Management Thought, The Ronald Press, New York. NY.

Wren, D.A. (1994), The Evolution of Management Thought, 4th ed., Wiley, New York, NY.

Wren, D.A. (2001), "Henri Fayol as a strategist: a nineteenth century corporate turnaround", Management Decision, Vol. 39 Nos 5/6, pp. 475-87. 